\title{
IMPROVEMENT OF PRACTICAL TRAINING OF EDUCATION MANAGERS AT UNIVERSITY \\ BY MEANS OF MENTORING AND FACILITATION
}

\section{УДОСКОНАЛЕННЯ ПРАКТИЧНОЇ ПІДГОТОВКИ МЕНЕДЖЕРІВ ОСВІТИ В УНІВЕРСИТЕТІ ЗАСОБАМИ НАСТАВНИЦТВА ТА ФАСИЛІТАЦЇ̈}

\section{Lenina Zadorozhna-Knyagnitska ${ }^{1}$}

DOI: https://doi.org/10.30525/978-9934-588-15-0-8

\begin{abstract}
The problem of practical training of education managers at universities is the one of current importance in modern theory and practice of professional training of specialists at universities. However, progress in solving this problem is impeded by the presence in academic groups of students with different levels of educational background and different management experience. The article proposes a methodology for organization of students' continuous practice which provides an individual educational trajectory and constant educational and methodological support for students without management experience through mentoring and facilitation. The main point of practice is dividing its contents into compulsory and elective modules. The tasks of the compulsory module were fulfilled by the students who had no experience in holding the position of an educational institution manager; the elective module contained a set of tasks for the students who held senior positions in institutions of general education and acted as mentors for their group mates who had no work experience. In addition, the educational program partners - heads of educational institutions who had received a master degree in previous years were involved in the process of practical training. It was hypothesized that such arrangement of practice would significantly improve the quality of practical training of students with or without management experience. In order to confirm the hypothesis, during 2013-2018 a pedagogical
\end{abstract}

\footnotetext{
${ }^{1}$ Doctor of Pedagogical Sciences, Associate Professor, Head of the Chair of Pedagogy and Education, Mariupol State University, Ukraine 
experiment was conducted in 4 universities of Ukraine, which carry out training of education managers. By analyzing the results of the forming experiment there was determined positive dynamics in the indicators for the levels of practical abilities and skills formation, which confirms the general hypothesis of the pedagogical experiment. The author has proved that the effectiveness of professional training of education managers within the framework of continuous pedagogical practice is ensured by: adhering to the principles of interdisciplinary integration, unity of theory and practice, Masters' self-sufficiency and commitment, succession and prognostication of the results at every stage; involving a wide range of heads from preschool and general secondary education institutions as mentoring partners; providing an individual trajectory of practical training for each Master student. The practical significance of the thesis is manifested in developing and introducing the educational and methodological complex for practical training of students of the second level of higher education in specialty 073 Management (Educational Institution Management) and heads of general secondary education institutions.

\section{1. Вступ}

Формування управлінської компетентності менеджерів освіти неможливе поза практичним контекстом професійної підготовки. Практична підготовка спрямована на перетворення знань, отриманих добувачами вищої освіти за час навчання, в інструмент успішної професійної діяльності; вона є способом вивчення управлінського процесу на основі безпосередньої участі в ньому, сполучною ланкою між теоретичним навчанням здобувача вищої освіти і його самостійною професійною діяльністю, засобом розвитку творчої активності і саморозвитку майбутнього керівника, формування в нього професійних якостей і здатності до управлінської діяльності.

Результативність фахової підготовки менеджера освіти виявляється, перш за все, через його здатність ефективно діяти в межах виконання професійних функцій та вирішення управлінських завдань $[2 ; 7 ; 8 ; 15] .3$ огляду на зазначене, дослідження проблем практичної підготовки менеджерів освіти набувають особливої значущості. Ця проблема розглядається в межах комплексу методологічних підходів (діяльнісного, особистісного, синергетичного, аксіологічного, систем- 
ного, компетентісного) [3; 4; 18]. Домінуючу роль серед цих підходів відіграє діяльнісний, що розкриває діяльність здобувача вищої освіти як механізм перетворення зовнішніх впливів у новоутворення особистості та зумовлює використання освітніх технологій, провідною метою яких є формування способу дій [16].

Зазначені освітні технології базуються на комплексі організаційних принципів:

- міждисциплінарної інтеграції змісту, форм і методів навчання;

- самостійності й активності здобувача вищої освіти, що дозволяє виробити індивідуальний стиль діяльності, знайти оптимальні шляхи та засоби вирішення ситуацій у складних умовах професійної взаємодії;

- перспективного планування, наступності й прогнозованості результатів на кожному етапі;

- узгодженості вимог і дій керівників від бази практики та закладу вищої освіти, наставників щодо забезпечення самостійної професійної діяльності здобувачів вищої освіти;

- поглибленого спостереження та вивчення процесу становлення особистості фахівця;

- забезпечення можливостей для самореалізації у професійній діяльності $[5 ; 9 ; 12]$.

3 початку XXI століття у наукових джерелах широко обговорюються питання теорії і практики професійної підготовки менеджерів освіти. Ученими досліджено теоретичні засади фахової підготовки менеджерів освіти (В.С. Берека, Л.І. Даниленко, В.І. Жигірь, Т.А. Махиня), проблеми формування їхньої управлінської компетентності(В.К. Мельник, В.І. Маслов); обгрунтовано педагогічні умови, що забезпечують професійну підготовку менеджерів освіти до управління якістю освіти (Л.Е. Лунячек), управління ризиками (Н.М. Черненко), до інноваційного управління (Н.М. Сас); проаналізовано особливості професійної підготовки менеджерів освіти в системі неперервної педагогічної освіти (Л.М. Кравченко), розвитку професіоналізму менеджерів освіти у післядипломній педагогічній освіті (Л.В. Васильченко, Т.М. Пікож, Т.М. Сорочан).

Однак, незважаючи на значний інтерес дослідників до проблем професійної підготовки менеджерів освіти, у сучасній науковій літературі розкрито лише теоретичні підходи до організації виробничої практики здобувачів вищої освіти, визначено загальні рекомендації щодо ії здійснення 
без подання конкретної методики й організаційно-методичного супроводу практичної підготовки. Така ситуація не є випадковою, оскільки Законом України «Про вищу освіту» (2014) університетам надано академічну автономію, що дозволяє їм самостійно формувати зміст освітньо-професійних та освітньо-наукових програм. За таких умов програми практичної підготовки менеджерів освіти в різних університетах суттєво відрізняються за змістом та особливостями реалізації цього змісту.

Проблема організації практичної підготовки менеджерів освіти полягає в тому, що в Україні відсутні освітньо-професійні програми, орієнтовані на різні цільові групи студентів (керівники зі стажем управлінської діяльності, новопризначені або молоді керівники, педагоги зі стажем педагогічної, а не управлінської роботи, бакалаври освіти тощо). Наявність в академічних групах здобувачів вищої освіти 3 різним ступенем підготовленості та різним досвідом управлінської діяльності ускладнює їх якісну практичну підготовку. Зазначена проблема обумовила розробку й упровадження підходів до організації виробничої практики, які б забезпечили індивідуальну освітню траєкторію опанування програмою і постійний організаційно-методичний супровід здобувачів вищої освіти з різним рівнем підготовленості до управлінської діяльності.

Одним із шляхів вирішення проблеми якісної професійної підготовки менеджерів освіти в університетах є наставництво та фасилітація, що базуються на використанні потенціалу здобувачів вищої освіти, які вже мають досвід управління закладом освіти. Формальне та неформальне наставництво $є$ вагомим чинником створення сприятливого психологічного клімату протягом практики, забезпечує ефективну адаптацію до професійної діяльності, іiї рефлексію $[1 ; 20]$. Сутнісні характеристики наставництва та фасилітації виявляються у розумінні й підтримці здобувачами вищої освіти один одного, визнанні права кожного учасника освітнього процесу на власну думку, колективній відповідальності за прийняття рішень [19].

Враховуючи наявність у здобувачів вищої освіти, які вже працюють на керівних посадах, базових професійних знань, сформованої емпіричним шляхом управлінської компетентності та гарних організаційних якостей [14], можна припустити їх значну роль у забезпеченні практичної підготовки одногрупників без досвіду управлінської діяльності. 
Мета дослідження полягає в теоретико-методологічному обгрунтуванні, розробленні та експериментальній перевірці програми практичної підготовки менеджерів освіти в університетах засобами педагогічного наставництва та фасилітації.

Завдання дослідження:

1.Розкрити сутнісні характеристики та особливості організації практичної підготовки менеджерів освіти в університетах.

2. Розробити програму практичної підготовки менеджерів освіти на основі наставництва та фасилітації.

3.Експериментально перевірити ефективність розробленої програми практичної підготовки менеджерів освіти в університетах на основі педагогічного наставництва та фасилітації.

Методологічну основу дослідження становлять філософські положення гносеології щодо: діалектичного взаємозв'язку закономірностей та явищ педагогічної реальності; праксеології щодо принципів і шляхів підвищення ефективності професійної підготовки менеджерів освіти; професійного розвитку та саморозвитку особистості в системі неперервної педагогічної освіти; основні положення теорії систем, теорії управління; гуманістична, культурологічна парадигми; педагогічні концепції неперервної, особистісно-орієнтованої освіти; системний, синергетичний, компетентнісний, аксіологічний, акмеологічний підходи.

Дослідження базується на принципах системності, науковості, творчого підходу до особистості як суб єкта освітнього процесу. Наукова новизна даного дослідження полягає у тому, що вперше розроблено й науково обгрунтовано комплекс навчально-методичного забезпечення практичної підготовки для здобувачів другого ступеню вищої освіти спеціальності 073 Менеджмент (Управління закладом освіти) і керівників закладів загальної середньої освіти.

\section{2. Загальна характеристика неперервної практики менеджерів освіти}

Виробнича практика $є$ невід'ємною складовою освітньо-професійної програми підготовки здобувачів вищої освіти, що спрямована на закріплення теоретичних знань, отриманих ними за час навчання, набуття й удосконалення практичних навичок і вмінь; способом 
вивчення управлінського процесу на основі безпосередньої участі в ньому; сполучною ланкою між теоретичним навчанням здобувача вищої освіти і його майбутньою самостійною професійною діяльністю на посаді керівника закладу освіти; засобом розвитку творчої активності й саморозвитку керівника, формування в нього професійно значущих якостей і готовності до управлінської діяльності.

Практична підготовка менеджерів освіти в університетах базується на наступних принципах:

- міждисциплінарної інтеграції змісту, форм і методів навчання;

- самостійності й активності здобувачів вищої освіти, що дозволяє виробити індивідуальний управлінський стиль, знайти оптимальні шляхи та засоби розв'язання професійних ситуацій у складних умовах управлінської взаємодії;

- індивідуалізації та диференціації, що передбачає освоєння здобувачами вищої освіти індивідуальної траєкторії практичної діяльності в межах обов'язкового та вибіркового модулів з урахуванням рівня їх професійної спрямованості, загальної та професійної підготовки;

- перспективного планування, наступності й прогнозованості результатів на кожному етапі;

- узгодженості вимог і дій керівників від бази практики та закладу вищої освіти, наставників щодо забезпечення самостійної управлінської діяльності здобувачів вищої освіти;

- поглибленого спостереження та вивчення процесу становлення особистості менеджера освіти;

- забезпечення можливостей для самореалізації в управлінській діяльності $[2 ; 5 ; 9 ; 10]$.

Неперервна практика магістрів містить у собі три взаємопов'язані етапи: пропедевтичний, адаптаційний та технологічний.

Перебіг пропедевтичного етапу практичної підготовки не є самостійним, - він є складовою процесу оволодіння здобувачами вищої освіти змістом навчальних дисциплін першого семестру, практична спрямованість яких реалізується засобами виконання здобувачів вищої освіти комплексу практичних завдань:

- опрацювання змісту нормативних документів, якими керується у своїй діяльності директор школи, та обгрунтування змісту його відповідальності за кожним з документів; 
- аналіз, співставлення, порівняння різних стратегій поведінки менеджера освіти (на базі закладу освіти, де працює здобувач вищої освіти);

- виявлення співвідношення освітньої практики та державних вимог до менеджера освіти;

- моделювання та створення професійного іміджу, що відповідає моральним і професійним очікуванням колективу;

- аналіз професійних ситуацій, свідками чи учасниками якої були здобувачі вищої освіти.

Адаптаційний етап практичної підготовки, що здійснюється в межах виробничої практики з атестації педагогічних кадрів (в якості керівника закладу освіти), охоплює спектр питань першого рівня управлінського циклу.

Метою виробничої практики 3 атестації педагогічних кадрів $\epsilon$ поглиблення теоретичних знань та формування у здобувачів вищої освіти професійних умінь і навичок, а також формування в основних професійних компетенностей менеджера освіти (аналітико-синтетичної, комунікативної, прогностичної, організаторської, мотиваційної) та здатності будувати управлінську діяльність на засадах деонтологічного, акмеологічного та гуманістичного підходів.

Виробнича практика 3 атестації педагогічних кадрів здійснюється протягом другого семестру з урахуванням обов'язкового мінімуму змісту програми професійної підготовки менеджера освіти. Програма зазначеної практики містить завдання, які дають можливість узагальнити знання, практичні вміння та навички на базі конкретного закладу освіти, оволодіти професійним досвідом, перевірити готовність до самостійної трудової діяльності. Вона передбачає вивчення особливостей організації системи заходів щодо атестації педагогічних кадрів, здійснення моніторингу результативності професійної діяльності педагогічних працівників протягом міжатестаційного періоду; особливостей науково-методичного забезпечення атестаційних процедур [6, с. 13].

Технологічний етап практичної підготовки здійснюється в межах інспекторсько-методичної виробничої практики у третьому семестрі. Метою цього етапу є поглиблення й закріплення теоретичних знань та формування у здобувачів вищої освіти професійних умінь і навичок діяльності інспектора та методиста Департаменту освіти, а також фор- 
мування потреби систематично поповнювати свої знання і творчо їх застосовувати в практичній діяльності.

Програма зазначеної виробничої практики містить завдання, що дають можливість узагальнити знання, практичні вміння та навички, оволодіти професійним досвідом, перевірити готовність майбутнього фахівця до самостійної трудової діяльності. Така виробнича практика передбачає вивчення особливостей організації структури та діяльності Департаменту освіти, посадових обов'язків спеціаліста, нормативної бази його діяльності та організації й проведення інспекторських перевірок діяльності закладів освіти, а також виконання самостійних завдань, що стосуються професійної діяльності інспектора та методиста [6, с. 16].

Отже, період професійної підготовки на другому рівні вищої освіти слід розглядати як безперервну виробничу практику, загальною метою якої $\epsilon$ формування у здобувачів вищої освіти стійкої позитивної мотивації до професійної діяльності, поглиблення й закріплення теоретичних знань та формування в них умінь і навичок вирішення проблем та завдань організаційно-управлінської діяльності.

\section{3. Зміст програми практичної підготовки менеджерів освіти на основі наставництва та фасилітації}

Для забезпечення більш якісної практичної підготовки здобувачів магістерського ступеня за спеціальністю «Менеджмент. Управління закладом загальної середньої освіти» у Маріупольському державному університеті було розроблено програму виробничої практики [6], що містить у собі чотири основних взаємопов'язаних етапи: організаційно-методичний, операційно-діяльнісний, контрольно-оцінювальний та аналітико-результативний, кожний з яких має своє змістове наповнення.

Завдання практики продиктовані не лише вимогами освітньої програми, але й необхідністю надання практикантам завдань різного ступеню складності, що обумовлюється наявністю в академічних групах як осіб з досвідом управлінської діяльності (які вже займають керівні посади у закладах освіти), так і здобувачів вищої освіти без такого досвіду. 3 огляду на зазначене, було упроваджено такі заходи:

- до змісту практики було внесено завдання, що розподілені на два змістові модулі - обов'язковий та вибірковий (завдання обов'яз- 
кового модуля виконуються здобувачами вищої освіти, які не мають досвіду роботи на посаді керівника закладу освіти, вибірковий модуль $\epsilon$ основним комплексом завдань для здобувачів вищої освіти, які обіймають керівні посади в закладах загальної освіти);

- здобувачів вищої освіти, які не мають досвіду управлінської діяльності було направлено на практику до тих закладів освіти, керівниками яких є здобувач вищої освіти цієї ж академічної групи. Таким чином керівники закладів освіти виконували обов'язки своєрідних наставників для здобувачів вищої освіти без управлінського досвіду.

Зміст основного та вибіркового модулів на кожному етапі виробничої практики показано в таблиці 1 .

Особливістю організації виробничої практики $є$ й активна участь у ній в якості менторів керівників закладів освіти міста, які $є$ випускниками спеціальності «Менеджмент. Управління закладом загальної середньої освіти» різних років. Основним завданням таких осіб $\epsilon$ надання консультативної допомоги у прийнятті управлінського рішення, виконання обов'язків експертів під час оцінки звітних доповідей здобувачів вищої освіти на конференції за підсумками

Таблиця 1

Зміст обов'язкового та вибіркового модулів виробничої практики в якості керівника закладу освіти

\begin{tabular}{|c|c|}
\hline Обов'язковий модуль & Вибірковий модуль \\
\hline \multicolumn{2}{|c|}{ Організаційно-методичний етап } \\
\hline \multicolumn{2}{|c|}{$\begin{array}{l}\text { Завдання етапу: підготовка до проходження виробничої практики з атестації } \\
\text { педагогічних кадрів. }\end{array}$} \\
\hline $\begin{array}{l}\text { Алгоритм дій у межах етапу: } \\
\text { 1. Участь в установчій конференції } \\
\text { та методичному семінарі з питань } \\
\text { організації виробничої практики. } \\
\text { 2. Складання індивідуального плану } \\
\text { і його затвердження в керівника } \\
\text { практики від випускової кафедри. } \\
\text { 3. Ознайомлення з нормативними } \\
\text { документами щодо атестації педагогів, } \\
\text { особливостей планування, підготовки } \\
\text { та проведення атестаційних процедур, } \\
\text { змістом діяльності керівника закладу } \\
\text { освіти в контексті атестації педагогів. }\end{array}$ & $\begin{array}{l}\text { Алгоритм дій у межах етапу: } \\
\text { 1. Участь в установчій конференції } \\
\text { та методичному семінарі з питань } \\
\text { організації практики. } \\
\text { 2. Складання індивідуальної програми } \\
\text { практики та затвердження в керівника } \\
\text { практики від випускової кафедри. }\end{array}$ \\
\hline
\end{tabular}


Продовження таблиці 1

\begin{tabular}{|c|c|}
\hline \multicolumn{2}{|c|}{ Діяльнісно-операційний етап } \\
\hline $\begin{array}{l}\text { Завдання етапу: формування умінь } \\
\text { та навичок управлінської діяльності } \\
\text { в межах обов язків керівника закладу } \\
\text { освіти. } \\
\text { Алгоритм дій в межсах етапу: } \\
\text { 1. Вивчення досвіду роботи закладу } \\
\text { освіти щодо організації та проведення } \\
\text { атестації педагогічних працівників: } \\
\text { ознайомлення з нормативно- } \\
\text { інструктивною та методичною базою } \\
\text { атестації педагогічних кадрів, опис } \\
\text { етапів атестаційного періоду; вивчення } \\
\text { змісту документів у папці «Атестація»; } \\
\text { ознайомлення з матеріалами «куточка } \\
\text { атестації». } \\
\text { 2. Формулювання висновків щодо } \\
\text { відповідності діяльності керівника } \\
\text { закладу освіти методичним } \\
\text { рекомендаціям щодо змісту його } \\
\text { діяльності під час атестаційного періоду. } \\
\text { 3. Дослідження особливостей } \\
\text { планування роботи керівника закладу } \\
\text { освіти протягом поточного навчального } \\
\text { року, місяця, тижня, оперативне } \\
\text { планування роботи у контексті } \\
\text { проведення атестації педагогів. } \\
\text { 4. Відвідання та аналіз двох відкритих } \\
\text { уроків педагогами, які атестуються. } \\
\text { 5. Спостереження та аналіз двох } \\
\text { творчих звітів педагогів, які } \\
\text { атестуються. } \\
\text { 6. Вивчення особливостей діяльності } \\
\text { атестаційної комісії. } \\
\text { 7. Ознайомлення зі змістом } \\
\text { атестаційної папки педагога. }\end{array}$ & $\begin{array}{l}\text { Завдання етапу: вдосконалення умінь } \\
\text { та навичок управлінської діяльності } \\
\text { в межах обов’язків керівника закладу } \\
\text { освіти. } \\
\text { Алгоритм дій в межах етапу: } \\
\text { 1. Ознайомлення здобувачів вищої } \\
\text { освіти без досвіду управлінської } \\
\text { діяльності з нормативними } \\
\text { документами щодо атестації } \\
\text { педагогічних кадрів, особливостей } \\
\text { організації атестаційних процедур, } \\
\text { моніторингу професійної діяльності } \\
\text { педагогів у між-атестаційний період. } \\
\text { 2. Організація та проведення творчих } \\
\text { звітів педагогів закладу освіти. } \\
\text { 3. Надання консультацій практикантам } \\
\text { (у межах завдань практики), які } \\
\text { не мають досвіду управлінської } \\
\text { діяльності. } \\
\text { 4. Вивчення досвіду роботи іншого } \\
\text { закладу освіти - бази практики, щодо } \\
\text { організації та проведення атестації } \\
\text { педпрацівників. } \\
\text { 5. Дослідження особливостей } \\
\text { планування роботи керівника іншого } \\
\text { закладу освіти поточного навчального } \\
\text { року, місяця, тижня, оперативне } \\
\text { планування роботи в контексті } \\
\text { проведення атестації педагогів. } \\
\text { 6. Спостереження та аналіз двох } \\
\text { творчих звітів педагогів інших баз } \\
\text { практики, які атестуються. } \\
\text { 7. Проведення й обговорення } \\
\text { педагогічної наради з питань атестації } \\
\text { педагогічних кадрів. }\end{array}$ \\
\hline \multicolumn{2}{|c|}{ Контрольно-оцінювальний етап } \\
\hline $\begin{array}{l}\text { Завдання етапу: оцінювання базами } \\
\text { практики діяльності здобувачів } \\
\text { вищої освіти, підготовка звітної } \\
\text { документації, аналіз та самоаналіз } \\
\text { практичної підготовки. }\end{array}$ & $\begin{array}{l}\text { Завдання етапу: підготовка звітної } \\
\text { документації, аналіз та самоаналіз } \\
\text { виробничої практики. }\end{array}$ \\
\hline
\end{tabular}


Закінчення таблиці 1

Алгоритм дій в межах етапу:

1. Попереднє обговорення з керівником бази практики результатів її проходження.

2. Підготовка звітних матеріалів із практики, аналіз результативності діяльності

менеджера освіти в контексті організації та здійснення атестації педагогічних кадрів.

3. Здійснення самоаналізу діяльності протягом практики.

\section{Аналітико-результативний етап}

Завдання етаny: аналіз результативності практики, оцінка та самооцінка вмінь та навичок здобувачів вищої освіти щодо реалізації основних функцій керівника закладу освіти в межах атестації педагогічних працівників.

Алгоритм дій в межах етапу:

1. Підготовка до презентації портфоліо.

2. Участь у підсумковій конференції за результатами практики.

3. Формулювання рекомендацій щодо вдосконалення організації виробничої практики з атестації педагогічних кадрів (в якості керівника закладу освіти).

практики, презентація управлінського досвіду та участь у професійних дискусіях.

Зокрема, за активного сприяння керівників закладів освіти протягом 2014-2018 рр. організовано такі заходи:

- методичні семінари («Завдання керівника закладу освіти у контексті реалізації положень Концепції Нової української школи», «Нормативна база діяльності освітньо-консалтингових центрів», «Проблема реформування функцій департаменту освіти в умовах децентралізації управління освітою», «Професійна відповідальність інспектора та методиста» тощо);

- дебати на базі одного з центральних в освітньому окрузі закладів загальної середньої освіти («Роль керівника методичного об єднання у забезпеченні професійного зростання молодого педагога», «Кар’єрний розвиток керівника: етапи, умови, очікування», «Чинники підвищення мотивації педагога до професійного вдосконалення: особисті висновки», «Інспекція закладу освіти: суб'єктивний погляд на об'єктивні обставини», «Звітність закладу освіти у вимірах боротьби з бюрократизмом», «Система «Прозоро». А чи прозоро?...» тощо;

- майстер-класи педагогів та керівників закладів загальної середньої освіти (проведення педагогічних нарад за результатами інспекторських перевірок, засідань піклувальної ради, звітів школи, батьківських конференцій тощо). 
Отже, методичний супровід практичної підготовки здобувачів магістерського ступеня на основі наставництва та фасилітації являє собою неперервне цілеспрямоване їх залучення до різних видів практичної професійної діяльності, до виконання функцій керівника, а також актуалізація їх управлінського досвіду.

Вагомою складовою забезпечення ефективності практичної підготовки менеджерів освіти в університетах є здійснюваний керівниками практики контроль діяльності практикантів. Завданням поточного контролю виробничої практики з атестації педагогічних кадрів $\epsilon$ перевірка виконання здобувачем вищої освіти поточних завдань практики, здатність використовувати набуті протягом теоретичної підготовки знання в конкретній ситуації в межах управлінського циклу, розробка й використання форм та методів управління діяльністю трудового колективу в межах виконання обов'язків керівника закладу освіти. Завданням підсумкового контролю $є$ перевірка результатів проходження здобувачами вищої освіти виробничої практики, систематизація й узагальнення набутих знань, вмінь і навичок.

Виробнича практика здобувачів вищої освіти завершується диференційованим заліком за системою, яку складає сума балів, накопичена практикантами під час виконання завдань обов'язкового чи вибіркового модулів практики. Разом із тим, враховуючи ту обставину, що зміст виробничої практики зі спеціальності не $\epsilon$ формальним вивченням особливостей професійної діяльності керівника закладу освіти, інспектора чи методиста та не передбачає копіювання стилю роботи прикріпленого до практиканта фахівця-наставника, кінцева оцінка за практику не може розцінюватися як арифметична сума балів, виставлених за певний вид роботи. Тому під час оцінювання результатів практики враховуються такі показники: організованість і дисциплінованість практиканта в період проходження практики; ініціатива і творчість, виявлені під час проходження практики на різних ділянках роботи; якість виконуваних завдань; критичність мислення, що презентується здобувачем вищої освіти під час практики; якість оформлення звітної документації; оцінка, яку пропонує наставник; своєчасність подачі документації; участь у науково-методичних семінарах. 


\section{4. Організація та проведення експериментальної роботи}

Метою експерименту $є$ перевірка гіпотези, що практична підготовка менеджерів освіти в університетах набуває ефективності, якщо забезпечено індивідуалізацію та диференціацію завдань практики, що передбачає освоєння здобувачами вищої освіти індивідуальної траєкторії практичної діяльності у межах обов'язкового та вибіркового модулів з урахуванням рівня професійної підготовленості, загальної та професійної підготовки здобувачів магістерського ступеня.

У межах проведеного експерименту було розроблено й упроваджено описану вище програму неперервної виробничої практики магістрів - менеджерів освіти. Виконання здобувачами вищої освіти програми практики здійснювалося під загальним контролем викладачів університету. Однак значну роль у цьому процесі відігравали магістри - керівники закладів освіти, які частково виконували функції наставника й фасилітатора для своїх одногрупників, здійснюючи консультування здобувачів вищої освіти без досвіду управлінської діяльності у процесі виконання ними поточних завдань практики, обговорення з ними дій керівника у вирішенні конкретної професійної ситуації, надаючи допомогу у розробці й використанні форм та методів управління діяльністю трудового колективу в межах виконання обов'язків керівника закладу освіти.

Враховуючи особливі умови проведення експерименту (неможливість виокремлення контрольної й експериментальної груп), для підтвердження гіпотези дослідження було проведено сукцесивний (послідовний) педагогічний експеримент, у межах якого одна і та ж група є контрольною на початку навчання в університеті (до введення експериментального фактора) та експериментальною по завершенню навчання (після того, як дія фактора відбулася).

Було проведено чотири цикли експерименту: протягом 2013-2018 pр. на базі Маріупольського державного університету та протягом 2016-2018 pp. - на базі Мелітопольського державного педагогічного університету ім. Богдана Хмельницького, Житомирського державного університету імені Івана Франка, Східноукраїнського національного університету імені Володимира Даля.

Розподіл студентів на дві групи здійснено за критерієм наявності в кожного $з$ них досвіду управлінської чи педагогічної діяльності: 
вибірка В1 (студенти з досвідом професійної діяльності - 452 особи), вибірки В2 (студенти без досвіду професійної діяльності - 125 осіб).

Для одержання достовірної інформації про рівень сформованості професійних умінь менеджерів освіти в університетах було використано методику «Управлінські задачі» (С. В. Соловйов), методику «Шкала самоефективності» (Р. Шварцер та М. Срусалем), тест на визначення рівня суб'єктивного контролю (Дж. Роттер).

Існують вагомі аргументи на користь використання саме цих методик у межах дослідження. Методика С. Соловйова «Управлінські задачі» $є$ проектною методикою й спрямовується на визначення наявності умінь організації діяльності колективу, управлінських навичок, стилю управління, управлінських дій [13, с. 34]. Опитувальник «Рівень суб'єктивного контролю» (Дж. Роттер) та методика «Шкала самоефективності» (Р. Шварц та М. Срусалем) належать до ситуаційних тестів що передбачають вибір варіанту поведінки в певній соціальній (професійній) ситуації, близькій до реальної. За допомогою зазначених методик діагностуються, зокрема, такі аспекти особистості, як схильність до стабільних, стійких рішень і дій. Методика визначення локусу контролю Дж. Роттера використовується з метою визначення причинно-наслідкової інтерпретації поведінки (каузальної атрибуції) [13], ключову роль у якій відіграє локус суб'єктивного контролю. Саме локус контролю є показником загальної інтернальності, тобто поведінки особи, яка приймає відповідальність за те, що з нею відбувається, отже відображає уміння брати на себе відповідальність. Цільова зорієнтованість зазначених діагностичних методик на визначення практичних умінь та навичок, здатності брати на себе відповідальність обумовили їх використання для оцінки рівня сформованості професійних умінь і навичок здобувачів вищої освіти.

Експеримент передбачав виконання комплексу завдань, а саме: визначення рівня сформованості професійних умінь та навичок здобувачів магістерського ступеня на початку навчання в університеті; експериментальну перевірку ефективності розробленої програми виробничої практики на основі визначення рівня сформованості професійних умінь та навичок здобувачів після проходження ними неперервної практики; визначення напрямів удосконалення практичної підготовки менеджерів освіти в університетах. 
Оцінка сформованості діяльнісного компоненту професійної компетентності здобувачів магістерського ступеня здійснювалася за визначеними критеріями:

- сформованість професійно значущих умінь і навичок (ступінь сформованості самоефективності як здатності управляти своїм розвитком і діяльністю 3 метою ефективного досягнення поставлених управлінських цілей, уміння створювати власні способи вирішення професійних ситуацій) (F1);

- володіння технологією ефективної управлінської поведінки (здатність здійснювати управлінську поведінку, використовувати морально-правові способи регулювання управлінських відносин, продуктивно організовувати діяльність та спілкування в трудовому колективі тощо) (F1);

- володіння методиками здійснення рефлексивного аналізу власної діяльності (ступінь сформованості локусу суб'єктивного контролю як показника загальної інтернальності, що відображає уміння керівника брати на себе відповідальність) (F1).

Було виділено 4 рівні сформованості професійних умінь студентів (критичний, базовий, функціональний, оптимальний) та було обрано базовий (еталонний) показник - 1 бал.

Отже, у межах дослідження, оцінюючи рівень сформованості професійних умінь студентів було використано таку шкалу:

$-0<\mathrm{P} \leq 0,49$ - сформованість практичних умінь та навичок $є$ недостатньою (критичний рівень);

- 0,50 < $\mathrm{P} \leq 0,74$ - сформованість практичних умінь та навичок $\epsilon$ задовільною (базовий рівень);

- 0,75 < $\mathrm{P} \leq 0,89$ - сформованість практичних умінь та навичок $\epsilon$ достатньою (функціональний рівень).

$-0,90<\mathrm{P} \leq 1-$ сформованість практичних умінь та навичок $\epsilon$ високою (оптимальний рівень).

Таким чином, методика експериментальної роботи полягала у виділенні та реалізації завдань дослідження рівня сформованості практичних знань та навичок студентів; застосуванні факторного, параметричного, порівняльного видів аналізу з метою встановлення динаміки зрушень за визначеними критеріями та показниками. 


\section{5. Результати експерименту}

На початку експерименту за результатами вхідних замірів виявлено, що у більшості респондентів $(58,5 \%)$ групи В1 наявний базовий рівень сформованості професійних умінь та навичок, 25\% склали респонденти 3 функціональним, 13\% - 3 оптимальним рівнем; було виявлено й незначний відсоток респондентів 3 критичним рівнем $-3,5 \%$. У межах групи В2 респонденти розподілилися наступним чином: критичний рівень - 54\%, базовий рівень - 36\%, функціональний - $10 \%$.

Пропорції розподілу за рівнями сформованості професійних умінь та навичок студентів за результатами вхідних замірів за 2013-2016 pp. (у\%) відображено на рисунку 1.

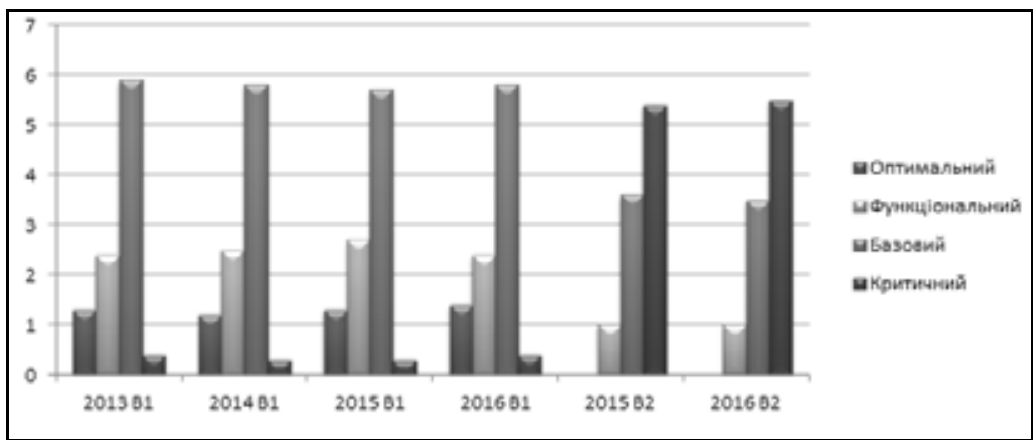

Рис. 1. Розподіл за рівнями сформованості професійних умінь і навичок магістрів за результатами вхідних замірів 3a 2013-2016 pp. (y \%)

За результатами констатувального експерименту виявлено суттєвий дисбаланс між рівнем сформованості умінь і навичок та рівнем самоефективності менеджерів освіти, що розуміється як продуктивний процес інтеграції когнітивних, соціальних та поведінкових компонентів задля здійснення оптимальної стратегії в різноманітних ситуаціях управлінської взаємодії.

Результати дослідження засвідчують наявність високої та помірної самоефективності в більшості респондентів групи В1 (відповідно 48\% та 52\%), що свідчить про очікування успіху, впевненості у правильності власних дій, самостійності у виборі стратегії професійної пове- 
дінки. Однак респонденти цієї групи не продемонстрували високого ступеню сформованості практичних умінь та навичок у межах розв `язання актуальних задач професійної діяльності. У цій групі лише 13\% респондентів виявили оптимальний рівень сформованості таких умінь та навичок, функціональний - 25\%, базовий - 58,5\%, 3,5\% - критичний рівень.

У групі В2 такий дисбаланс відсутній, однак більшість респондентів цієї групи виявили базовий (36\%) та критичний (54\%) рівень сформованості практичних умінь та навичок, що свідчить про наявність невпевненості у правильності своїх дій, визнанні власної нездатності або часткової здатності справлятися зі складними управлінськими ситуаціями, постійної самокритики з приводу власної некомпетентності. Лише $10 \%$ респондентів мали функціональний рівень сформованості практичних умінь та навичок.

Метою формувального етапу дослідно-експериментальної роботи було упровадження програми виробничої практики на основі наставництва та фасилітації. Розвиток професійних умінь здобувачів вищої освіти здійснювався в організаційно-методичних умовах, що передбачали: організаційно-методичний супровід процесу практичної підготовки, створення професійно насиченого освітнього середовища через наставництво та залучення до освітнього процесу в якості експертів та рецензентів партнерів освітньої програми, якими є керівники закладів загальної середньої освіти, що вже мають освітній ступінь магістра менеджменту освіти.

На основі аналізу результатів формувального експерименту було виявлено, що показники рівня сформованості практичних умінь і навичок студентів зазнали суттєвих позитивних змін. За вибіркою В1 така динаміка становила $+0,35$, за вибіркою В2 $+0,40$. Загальну тенденцію щодо рівня сформованості практичних умінь та навичок студентів за результатами вхідного й вихідного замірів представлено на рисунку 2.

Окрім того, у процесі аналізу результатів дослідження було виявлено відсутність у групі В1 дисбалансу між рівнем сформованості професійних умінь і навичок та рівнем самоефективності здобувачів вищої освіти, що мав місце на початку експерименту.

У більшості респондентів (52\%) групи В1 було виявлено оптимальний рівень сформованості практичних умінь та навичок, 46\% склали 


\section{Lenina Zadorozhna-Knyagnitska}

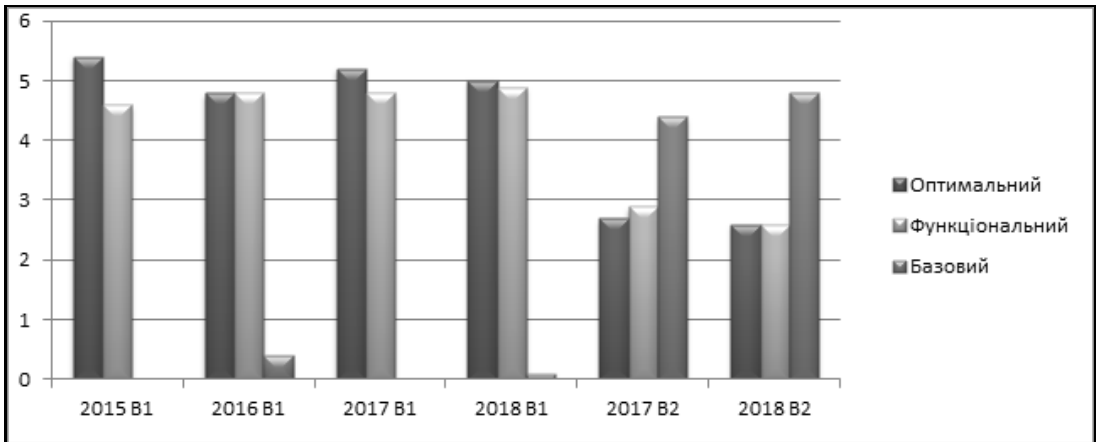

Рис. 2. Розподіл за рівнями сформованості професійних умінь і навичок магістрів за результатами вхідних замірів 3a 2015-2018 pp. (y \%)

респонденти з функціональним рівнем; було виявлено й незначний відсоток респондентів з базовим рівнем - 2\%. У межах групи В2 респонденти розподілилися наступним чином: базовий рівень $-46 \%$, функціональний - 34\%, оптимальний $-20 \%$.

Узагальнені результати вимірювання вихідного рівня сформованості професійних знань та умінь здобувачів магістерського ступеня представлено в таблиці 2.

Динаміка зрушень у показниках рівнів сформованості практичних умінь та навичок здобувачів вищої освіти підтверджує загальну гіпотезу педагогічного експерименту і доводить дієвість програми виробничої практики практики менеджерів освіти в університетах.

\section{6. Висновки}

Результати здійсненого дослідження дозволяють зробити такі висновки:

1.Розроблена та упроваджена програма практичної підготовки менеджерів освіти має низку переваг: надання подвійного цілеспрямованого впливу на здобувачів вищої освіти, що підвищує ефективність їх професійної підготовки; створення додаткових можливостей для здобувачів вищої освіти з досвідом роботи щодо їх самореалізації та ствердження позицій морального лідера; зміцнення міжособистісних 


\section{Узагальнені результати вимірювання}

вихідного рівня сформованості професійних знань

та умінь здобувачів магістерського ступеня

\begin{tabular}{|l|l|c|c|c|c|c|c|}
\hline \multirow{2}{*}{$\begin{array}{c}\text { Діяльнісний компонент } \\
\text { деонтологічної } \\
\text { компетентності }\end{array}$} & \multicolumn{3}{|c|}{ Рівень сформованості діяльнісного компоненту } \\
\cline { 3 - 8 } & $\mathbf{2 0 1 5}$ & $\mathbf{2 0 1 6}$ & \multicolumn{2}{|c|}{$\mathbf{2 0 1 7}$} & \multicolumn{2}{|c|}{$\mathbf{2 0 1 8}$} \\
\hline P1 & $\mathbf{B 1}$ & $\mathbf{B 1}$ & $\mathbf{B 2}$ & $\mathbf{B 1}$ & $\mathbf{\text { B2 }}$ \\
\hline P & $\begin{array}{c}0,97 \\
(+0,40)\end{array}$ & $\begin{array}{c}0,83 \\
(+0,29)\end{array}$ & $\begin{array}{c}0,91 \\
(+0,35)\end{array}$ & $\begin{array}{c}0,73 \\
(+0,39)\end{array}$ & $\begin{array}{c}0,90 \\
(+0,36)\end{array}$ & $\begin{array}{c}0,76 \\
(+0,41)\end{array}$ \\
\hline F1 & $\begin{array}{l}\text { Сформованість } \\
\text { професійно значущих } \\
\text { умінь і навичок. }\end{array}$ & $\begin{array}{c}0,99 \\
(+0,52)\end{array}$ & $\begin{array}{c}0,77 \\
(+0,31)\end{array}$ & $\begin{array}{c}0,82 \\
(+0,38)\end{array}$ & $\begin{array}{c}0,72 \\
(+0,40)\end{array}$ & $\begin{array}{c}0,82 \\
(+0,40)\end{array}$ & $\begin{array}{c}0,69 \\
(+0,38)\end{array}$ \\
\hline $\begin{array}{l}\text { Володіння технологією } \\
\text { ефективної управлін- } \\
\text { ської поведінки. }\end{array}$ & $\begin{array}{c}0,93 \\
(+0,38)\end{array}$ & $\begin{array}{c}0,83 \\
(+0,32)\end{array}$ & $\begin{array}{c}0,91 \\
(+0,35)\end{array}$ & $\begin{array}{c}0,76 \\
(+0,40)\end{array}$ & $\begin{array}{c}0,94 \\
(+0,40)\end{array}$ & $\begin{array}{c}0,82 \\
(+0,46)\end{array}$ \\
\hline F3 & $\begin{array}{l}\text { Володіння мето- } \\
\text { диками здійснення } \\
\text { рефлексивного аналізу } \\
\text { власної діяльності }\end{array}$ & $\begin{array}{c}1 \\
(+0,31)\end{array}$ & $\begin{array}{c}0,89 \\
(+0,23)\end{array}$ & $\begin{array}{c}1 \\
(+0,32)\end{array}$ & $\begin{array}{c}0,72 \\
(+0,36)\end{array}$ & $\begin{array}{c}0,94 \\
(+0,27)\end{array}$ & $\begin{array}{c}0,77 \\
(+0,40)\end{array}$ \\
\hline
\end{tabular}

зв'язків в академічний групі, створення професійно насиченого освітнього середовища, що позитивно впливає на формування професійної компетентності менеджерів освіти в університетах.

2.Ефективність безперервної виробничої практики менеджерів освіти в університеті зумовлюється: наступністю, наскрізністю практичної складової змісту професійної підготовки; конкретизацією завдань до кожного 3 чотирьох етапів організації практики (організаційно-методичного, операційно-діяльнісного, контрольно-оцінювального, аналітико-результативного); диференціацією практичних модулів - обов'язкового (для здобувачів вищої освтіи без досвіду управлінської діяльності) та вибіркового (для здобувачів вищої освіти 3 досвідом управлінської діяльності); профілізацією виробничих завдань; залученням в якості наставників досвідчених керівників закладів освіти, які здобули ступінь магістра менеджменту.

3. Своєрідна структура практики, що передбачає не лише виконання функцій керівника закладу освіти, а й тематичні виступи в межах управлінської асамблеї та дискусійних платформ, забезпечує рівні можливості для всіх учасників освітнього процесу щодо висловлення 
власної думки з приводу обговорюваних питань, розвиває культуру дискусії, сприяє розвитку інтересу, створює необхідне деонтологічне насичене середовище спілкування, що є необхідною організаційно-методичною умовою забезпечення професійної підготовки підготовки. Наукова комунікація за таких умов набуває вигляду регулювання (встановлення та підтримання режиму діяльності та поведінки ії учасників відповідно до наявних вимог діяльності) та співробітництва (спільна діяльність, в якій цілі та інтереси ії учасників збігаються).

Отже, залучення до практичної підготовки менеджерів освіти, які вже мають ступінь магістра та займають керівні посади в закладах освіти, значно збагачує здобувачів вищої освіти управлінським досвідом, суттєво актуалізує професійні знання та вміння, надає практичній підготовці рис дискусійної платформи, а професійній підготовці - особистісного забарвлення.

Матеріали дослідження можуть бути використані для розробки програм неперервної практики у межах професійної підготовки менеджерів освіти, програм підвищення кваліфікації педагогів у системі безперервної педагогічної освіти.

Подальшого дослідження потребує питання обгрунтування теоретичних і методичних засад розробки й упровадження індивідуальної освітньої траєкторії професійної підготовки майбутніх менеджерів освіти, зокрема у контексті формування практичних умінь та навичок.

\section{Список літератури:}

1. Armstrong S.J., Allinson C.W., Hayes J. Formal mentoring systems: An examination of the effects of mentor/protégé cognitive styles on the mentoring process. The Journal of Management Studies. 2002. № 39(8), pp. 1111-1135.

2. Берека В.С. Теоретико-методичні основи фахової підготовки магістрів з менеджменту освіти: дис. ... д-ра пед. наук : 13.00.04. Київ, 2008. 581 с.

3. Вітвицька С.С. Педагогічна підготовка магістрів в умовах ступеневої освіти: теоретико-методологічний аспект : монографія. Житомир, 2009. 440 с.

4. Гладкова В.М. Акмеологічні засади професійного самовдосконалення менеджерів вищих навчальних закладів: автореф. дис. ... д-ра пед. наук : 13.00.06. Київ, 2014. 40 с.

5. Драч I.I. Управління формуванням професійної компетентності магістрантів педагогіки вищої школи: теоретико-методичні засади : монографія. Київ, 2013. 456 с.

6. Задорожна-Княгницька Л.В. Комплекс навчально-методичного забезпечення практичної підготовки студентів ОС «Магістр» спеціальності 073 
«Менеджмент» (освітня програма «Управління навчальним закладом»). Маріуполь. 2017. 45 с.

7. Иваненко И.Ю. Подготовка руководителей школьных организаций в современной ситуации модернизации профессионального образования : дис. ... д-ра пед наук: 13.00.08. Оренбург, 2012. 322 с.

8. Калашнікова С.А. Теоретико-методологічні засади професійної підготовки управлінців-лідерів в умовах сучасних суспільних трансформацій : автореф. дис. ... д-ра пед. наук : 13.00.06. Київ, 2011. 36 с.

9. Кисла О.Ф. Зміст та навчально-методичне забезпечення педагогічної практики : навч.-метод посіб. Чернігів, 2010. 68 с.

10. Кравченко Л.М. Наукові основи підготовки менеджера освіти у системі неперервної педагогічної освіти : дис. ... д-ра пед. наук : 13.00.04. Київ, 2008. 526 с.

11. Лунячек В.Е. Теоретико-методологічні засади професійної підготовки керівних кадрів в умовах магістратури до управління якістю освіти : дис. ... д-ра пед наук : 13.00.04. Харків, 2012. 400 с.

12. Мачинська Н.I. Педагогічна освіта магістрантів вищих навчальних закладів непедагогічного профілю : монографія. Львів, 2013. 416 с.

13. Моргун В.Ф. Основи психологічної діагностики. Київ, 2009. 464 с.

14. Mullen E.J. Vocational and psychosocial mentoring functions: Identifying mentors who serve both. Human Resource Development Quarterly. 1998. № 9(4). P. 319-331.

15. Сас Н.М. Тенденції професійної підготовки майбутніх керівників навчальних закладів до інноваційного управління (теоретико-методологічний аспект) : дис. ... д-ра пед. наук : 13.00.04. Черкаси, 2015. 400 с.

16. Семиченко В.А. Пріоритети професійної підготовки: діяльнісний чи особистісний підхід? Неперервна професійна освіта: проблеми, пошуки, перспективи : монографія / за ред. І.А. Зязюна. Київ, 2000. С. 176-203.

17. Сисоєва С.О., Кристопчук Т.Є. Методологія науково-педагогічних досліджень : підруч. Рівне, 2013. 360 с.

18. Черненко H.M. Теоретичні і методичні засади підготовки майбутніх менеджерів освіти до управління ризиками у навчальних закладах : дис. ... д-ра наук : 13.00.04. Одеса, 2016. 510 c.

19. Ogienko O. Facilitation in the context of pedagogical activities. Advanced Education. 2016. Issue 5, pp. 85-89.

20. Woodd M. Mentoring in further and higher education: Learning from the literature. Education and Training. 1997. № 39(8/9), pp. 333-343.

\section{References:}

1. Armstrong S.J., Allinson C.W., Hayes J. (2002, December). Formal mentoring systems: An examination of the effects of mentor/protégé cognitive styles on the mentoring process. The Journal of Management Studies, vol. 39(8), pp. 1111-1135.

2. Bereka V.Ye. (2008). Teoretyko-metodychni osnovy fakhovoi pidhotovky mahistriv z menedzhmentu osvity [Theoretical-methodical foundations of of 
master's training in education management]. Unpublished doctoral dissertation, Institute of pedagogical education and adults' education of Academy of Pedagogical Science of Ukraine, Kyiv.

3. Vitvytska S.S. (2009). Pedahohichna pidhotovka mahistriv v umovakh stupenevoi osvity: teoretyko-metodolohichnyi aspekt [Pedagogical preparation of masters in the conditions of step education: theoretical and methodological aspect]. Zhytomyr: Vyd-vo ZhDU imeni I. Franka. (in Ukrainian)

4. Hladkova V.M. (2014). Akmeolohichni zasady profesiinoho samovdoskonalennia menedzheriv vyshchykh navchalnykh zakladiv [Acmeological grounds of professional self-improvement of managers of higher educational institution]. (PhD Thesis), University of Management Education, Kyiv.

5. Drach I.I. (2013). Upravlinnia formuvanniam profesiinoi kompetentnosti mahistrantiv pedahohiky vyshchoi shkoly: teoretyko-metodychni zasady [Management of formation of professional competence of masters of pedagogy of higher education: theoretical and methodical principles]. Kyiv: Dorado-Druk. (in Ukrainian)

6. Zadorozhna-Knyagnitska L.V. (2017). Kompleks navchal'no-metodychnoho zabezpechennya praktychnoyi pidhotovky studentiv OS «Mahistr» spetsial'nosti 073 «Menedzhment» (osvitnya prohrama «Upravlinnya navchal'nym zakladom») [Complex of educational and methodological support of practical training of students of the Master's degree program in specialty 073 «Management» (educational program «Management of an educational institution»)]. Mariupol. (in Ukrainian)

7. Ivanenko I.Yu. (2012). Podgotovka rukovoditeley shkolnyih organizatsiy v sovremennoy situatsii modernizatsii professionalnogo obrazovaniya [Training of heads of school organizations in the current situation of modernization of vocational education]. Unpublished doctoral dissertation, Russian State Pedagogical University named after A.I. Herzen, Sanct Petersburg.

8. Kalashnikova S.A. (2011). Teoretyko-metodolohichni zasady profesiinoi pidhotovky upravlintsiv-lideriv $\mathrm{v}$ umovakh suchasnykh suspilnykh transformatsii [Theoretical-methodical foundations of professional training of leaders-managers in the conditions of modern social transformations]. (PhD Thesis), University of Management Education, Kyiv.

9. Kysla O.F. (2010). Zmist ta navchalno-metodychne zabezpechennia pedahohichnoi praktyky [Content and educational support of pedagogical practice]. Chernihiv : ChNPU imeni T.H. Shevchenka. (in Ukrainian)

10. Kravchenko L.M. (2008). Naukovi osnovy pidhotovky menedzhera osvity u systemi neperervnoyi pedahohichnoyi osvity [Scientific bases of education manager training in the system of continuous pedagogical education]: Unpublished doctoral dissertation, Kiev.

11. Luniachek V.E. (2012). Teoretyko-metodolohichni zasady profesiinoi pidhotovky kerivnykh kadriv $\mathrm{v}$ umovakh mahistratury do upravlinnia yakistiu osvity [Theoretical and methodological foundations of professional training of leading personnel in the conditions of a magistracy to quality education management]. Unpublished doctoral dissertation, Kharkiv National Pedagogical University named after G.S. Skovoroda, Kharkiv. 
12. Machynska N.I. (2013). Pedahohichna osvita mahistrantiv vyshchykh navchalnykh zakladiv nepedahohichnoho profiliu. [Pedagogical education of masters of higher educational establishments of non-pedagogical profile]. Lviv: LvDUVS. (in Ukrainian)

13. Morhun V.F. (2009). Osnovy psykholohichnoi diahnostyky [Basics of psychological diagnostics]. Kyiv: Slovo. (in Ukrainian)

14. Mullen E.J. (1998). Vocational and psychosocial mentoring functions: Identifying mentors who serve both. Human Resource Development Quarterly, vol. 9(4), pp. 319-331.

15. Sas N.M. (2015). Tendentsii profesiinoi pidhotovky maibutnikh kerivnykiv navchalnykh zakladiv do innovatsiinoho upravlinnia (teoretyko-metodolohichnyi aspekt) [Trends in the training of future managers of educational institutions for innovation management (theoretical and methodological aspect]. Cherkasy National University named after Bogdan Khmelnitsky, Cherkasy. (in Ukrainian)

16. Semychenko V.A. (2000). Priorytety profesiinoi pidhotovky: diialnisnyi chy osobystisnyi pidkhid? [Priorities for vocational training: an activity or personality approach?]. Neperervna profesiina osvita: problemy, poshuky, perspektyvy [Continuing vocational education: problems, searchs, prospects]. Kyiv, pp. 176-203. (in Ukrainian)

17. Sysoieva S.O., Krystopchuk T.Ye. (2013). Metodolohiia naukovopedahohichnykh doslidzhen [Methodology of scientific and pedagogical research]. Rivne, Ukraine: Volynski oberehy. (in Ukrainian)

18. Chernenko N.M. (2016). Teoretychni $i$ metodychni zasady pidhotovky maibutnikh menedzheriv osvity do upravlinnia ryzykamy u navchalnykh zakladakh [Theoretical and methodical bases of future managers training to risk management in educational institution]. Southern Ukrainian National Pedagogical University named after K.D. Ushinsky, Odesa. (in Ukrainian)

19. Ogienko O. (2016). Facilitation in the context of pedagogical activities. Advanced Education, Issue 5, pp. 85-89.

20. Woodd M. (1997). Mentoring in further and higher education: Learning from the literature. Education and Training, vol. 39(8/9), pp. 333-343. 